\section{International Scientific Journal Theoretical \& Applied Science}

Ganiyu Adedayo Ajenikoko Department of Electronic \& Electrical Engineering, Ladoke Akintola University of Technology, P.M.B. 4000, Ogbomoso, Nigeria ajeedollar@gmail.com

p-ISSN: 2308-4944 (print) e-ISSN: 2409-0085 (online)

Year: 2017 Issue: 04 Volume: 48

Published: 11.04.2017 http://T-Science.org
Oluwatoyin Abdullateef Salami

Department of Electronic \& Electrical Engineering, Ladoke Akintola University of Technology, P.M.B. 4000, Ogbomoso, Nigeria

SECTION 6. Metallurgy and energy.

\title{
DEVELOPMENT OF A GENERALIZED TWO-PARAMETER TEMPERATURE BASED LINEAR MODEL FOR ASSESSMENT OF SOLAR IRRADIANCE ON NIGERIAN GEO-POLITICAL ZONES
}

\begin{abstract}
The output of light energy from the entire core of the sun measured at the earth is called the solar irradiance. The epileptic nature of power supply has made it a challenge to provide sufficient power and energy to the growing population. This paper develops a generalized two-parameter temperature based linear model for assessment of solar irradiance on Nigerian geo-political zones. The minimum and maximum monthly mean daily ambient temperature as well as the monthly mean daily global solar radiation from natural were collected and analysed over a twenty year period for seven selected locations on Nigerian geo-political zones. Appropriate mathematical notations were used to perform a stochastic analysis on the collected data to develop a generalized model. The performance evaluation of the generalized model was done by computing the t-value in terms of the mean-bias error (MBE) and the root mean square error (RMSE) with the analysis done at $95 \%$ confidence level. A low MBE value of 0.0327 suggests a good long-term representation of the physical problem.

The RMSE which was in the range of 0.1835 to 0.2887 is dilates the efficiency of the generalized model. Sokoto has a relatively high annual solar irradiance and far much more than the $1.361 \mathrm{KW} / \mathrm{m} 2 / \mathrm{d}$ benchmark. Maiduguri has the highest annual irradiance as compared to other locations used as case studies in this research paper. It also has the highest potential for the generation of solar energy. Maiduguri with an annual average solar irradiance of $5.89 \mathrm{kWh} / \mathrm{m} 2 /$ d is the least site under consideration. This signifies that Nigeria is a good site for solar exploration and has high solar energy feasibility, as Port-Harcourt (the site with lowest solar irradiance) is significantly above the standard value of annual average solar irradiance. Even though, the solar radiation is generally high throughout the year in Maiduguri, February - April appeared as the months with the highest solar radiation. August appeared as the month with lowest solar radiation. Jos had the best solar irradiance in the country thus representing a place of huge potential in the solar exploration market. Enugu and Port-Harcourt had low solar irradiance compared to other locations used in this paper. The global solar radiation intensity produced by the generalized model developed can be used in the design, analysis and performance estimation of the solar conversion system. The estimation of the average daily global solar radiation which is necessary for optimal economic sizing of solar photovoltaic systems will encourage extensive use of solar energy, which is an essential solution for high atmospheric pollution caused from fossil fuel combination.

The result from the research work shows that most parts of Nigeria have a very high climatic feasibility of generating renewable energy using solar energy that can be utilized for off grid rural electrification and further increase the total energy accessibility in the country.

Key words: Solar Irradiance, Climate Feasibility, Solar Energy, Renewable Energy, Solar Power, Generalized, RMSE, MBE, Global Solar.

Language: English

Citation: Ajenikoko GA, Salami OA (2017) DEVELOPMENT OF A GENERALIZED TWO-PARAMETER TEMPERATURE BASED LINEAR MODEL FOR ASSESSMENT OF SOLAR IRRADIANCE ON NIGERIAN GEO-POLITICAL ZONES. ISJ Theoretical \& Applied Science, 04 (48): 36-48.
\end{abstract}

Soi: http://s-o-i.org/1.1/TAS-04-48-7 Doi: crossef https://dx.doi.org/10.15863/TAS.2017.04.48.7

\section{Introduction}

Solar irradiance is the output of light energy from the entire core of the sun, measured at the earth. It is measured in $\mathrm{kWh} / \mathrm{m}^{2} / \mathrm{d}$. According to satellite observations of total solar irradiance, the average value of solar irradiance was thought to be approximately $1.366 \mathrm{kWh} / \mathrm{m}^{2} / \mathrm{d}$ varying slightly with solar activity, but recent calibrations of the relevant satellite observations indicate a value closer to $1.361 \mathrm{kWh} / \mathrm{m}^{2} / \mathrm{d}$ [NASA]. Dharnai village in the 
North-western state of Biharhas successfully constructed a solar micro-grid of 100-kilowatt $(\mathrm{kW})$, $70 \mathrm{~kW}$ electricity generation, and $30 \mathrm{~kW}$ for 10 solarpowered water-pumps, supply power and water to the village's 450 homes, 50 commercial operations, two schools, training centre and health care facilities. Battery storage ensures power around the clock. By implementing such scheme, Nigeria can effectively bridge the gap between black-out and total electricity [[18], [19], [12], [17], [26]].

Even with the recent reforms in the power sector, more than half of the country's population still lack access to electricity. The epileptic condition of the power sector can be attributed to the inadequate and inefficient power plants, poor transmission and distribution facilities and out-dated metering system used by electricity consumers. Suleiman Lawal Nadabo (2010) worked on Renewable Energy as a solution to Nigerian energy crisis. He investigated the potentials of renewable energy sources in Nigeria and how to support, promote and encourage the growth of renewable energy resources in Nigeria to close the gap of 60$70 \%$ of Nigerians that did not have access to energy that is environmentally friendly [[4], [8], [11], [2]].

Global solar radiation (GSR) is the sum of the direct and the diffuse solar radiation on a surface. The direct solar radiation is the solar radiation received from the sun without being scattered by the atmosphere. The diffused solar radiation is the solar radiation received from the sun with its direction changed due to scattering by the atmosphere. The knowledge of the availability of GSR data is of fundamental importance in order to utilize solar energy economically and efficiently. The direct normal irradiation (DNI) is very significant in concentrating solar thermal installations that track the position of the sun. This is essential for the design and evaluation of solar energy conversion system. GSR data are not measured at the forty-five meteorological stations in Nigeria. In the absence of these data, one has to rely on available methods of estimation as well as developing new ones. The availability of such data will encourage possible analysis of application and efficient utilization of solar energy in order to control GHC emissions [[16], [23], [1], [10]].

GSR is an important parameter necessary for most ecological models and serves as input for different photovoltaic conversion system, hence it is of economic importance to renewable energy alternative. The solar radiation reaching the earth surface depends on the climatic condition of the specific site location and this is necessary for accurate prediction and design of a solar energy system. When global solar radiation is used to generate electrical energy for any specific site location, a provision should be made to forecast solar energy which will convert it to electrical energy to recover the load demand, that is, the amount of solar energy for that place has to be known. Technology for measuring GSR is very expensive and has instrumental hazards. Though, solar radiation data are available in most meteorological stations, many stations in developind countries including Nigeria suffer from a shortage of these data. Alternative methods for estimating these data are necessary. One of these methods is the use of empirical models. Accurate modelling depends on the quality and quantity of the measured data used and is a good tool for generating global solar radiation at locations where measured data are not available.

Power and energy serve as indicators to the socio-economic development of a country. Electricity can be used as a yardstick to differentiate between the developed countries and the developing countries. Developed countries are continuously using their advanced technology in implementing new ways to generate enormous amount of power in order to satisfy their corresponding high power demand and thus paving way for further industrial and economic growth. Developing countries in which Nigeria is not left out however are several miles away to reach the power and energy prowess of the developed countries and this can be associated to the weak administrative structure, corruption in the necessary quarters, high population density and lack of adequate technical know-how regarding application of scientific methods towards maximum utilization of the available resources [[32], [29], [6], [5]].

Since electricity is very important for economic development of a country, finding a solution to end the aged long power problems of Nigeria is very imperative, one can learn from developed countries in the world that now generate more than enough electricity used to power households and industrial establishments. Countries like Germany, Spain and other European heavyweights are now running fully on power generated with the use of $100 \%$ renewable energy scheme.

\subsection{Renewable Energy}

Renewable energy is defined as energy collected from resources which are naturally replenished on a human timescale, such as sunlight, wind, rain, tides, waves, and geothermal heat. It refers to a type of energy which occurs naturally and is theoretically believed to be an inexhaustible source of energy. Renewable energy often provides energy in at least four important areas: electricity generation, air and water heating/cooling, transportation, and offgrid energy services [2]. One of the major advantages of renewable energy is that the primary sources (sun, water, wind) are very much free in nature and inexhaustible. This means that the cost of generating energy when making use of renewable energy is relatively cheap [[28], [25], [31], [30]].

1.2 Solar Energy for rural electrification 
Solar energy is simply defined as the energy gained by the earth as a result of light radiations from the sun. It is a very important and the most widely used form of renewable energy all around the world because the sun is a universal body. Solar energy has a wide range of applications and most especially it is used for power generation, domestic and commercial uses [[9], [13]]. A solar power system is a system assembled using the basic components required to produce electrical energy from the sun. It comprises of the connection of solar panel/module(a group of individual solar cells connected in series, parallel or series-parallel combinations to produce a standard output), charger controller(an electronic device that regulates the voltage from the solar panel array to ensure maximum transfer of energy and prevent over-charging of the battery bank), a power inverter(an electronic device that concert $12,24,48$, or higher volts DC from batteries or solar panels to $120 / 240$ volts AC to operate appliances and battery bank [[3], [21], [20], [7], [14]].

The need for a well-structured renewable energy scheme which exploits the climatic condition of these rural areas is very necessary. Most locations in Africa are characterised by high sunshine which makes solar energy, a very logical choice of renewable energy especially in the Sahara(North Africa) where country like Morocco now run the power generation fully on Solar energy [[24], [27], [15], [22].

\subsection{Locations Considered in the Analysis}

Seven locations: - Sokoto, Kaduna, Maiduguri, Jos, Ogbomoso, Enugu and Phort-Harcourt were considered in the analysis and their geographical locations on Nigerian map are as shown in Figure 1.

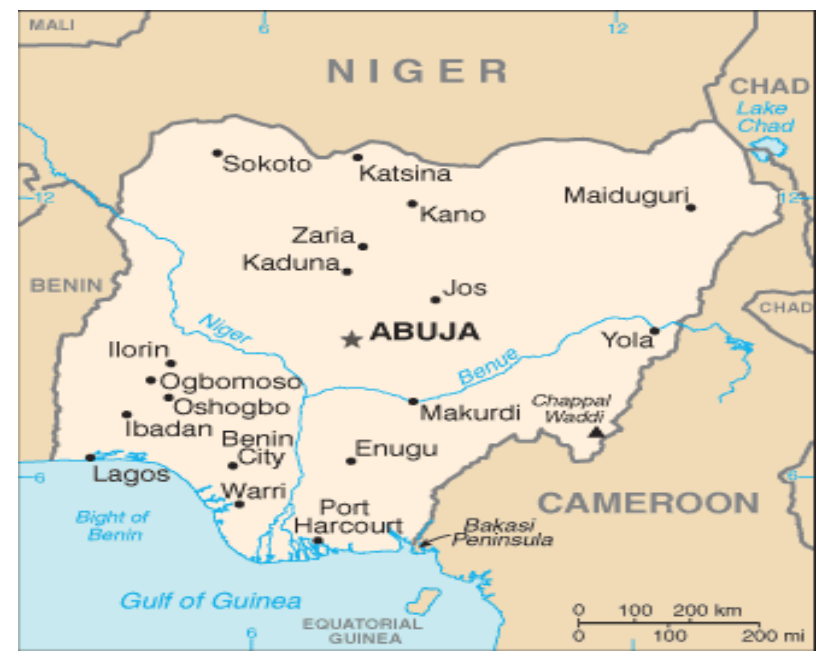

Figure 1 - Map of Nigeria showing the seven locations.

Since metrological data were not readily available for most rural areas in which off-grid electrification is intended, the main city close to areas were chosen. The latitudes and longitudes of both places are similar.

\subsubsection{Sokoto}

Sokoto is located in the North-west of Nigeria near the conference of Sokoto River and Rima River. It is the capital city of Sokoto state.

\subsubsection{Kaduna}

Kaduna is the state capital of Kaduna state in North central of Nigeria. On the Kaduna river, is a trade centre and a major transportation hub for the surrounding agricultural areas with its rail and road junction. With an annual average temperature of $24.6^{\circ} \mathrm{C}$, Kaduna is a good place for Solar Energy exploration for off-grid electrification. It also has a very thick population.

\subsubsection{Maiduguri}

Maiduguri is the capital and the largest city of Borno State in north-eastern Nigeria. It is located at latitude $11^{\circ} 50^{\prime} \mathrm{N}$ of the equator, and a longitude of $13^{\circ} 09^{\prime} \mathrm{E}$. The city sits along the seasonal Ngadda River which disappears into the Firki swamps in the areas around Lake Chad. Köppen-Geiger climate classification system classifies its climate as hot semi-arid. It has a temperature of as high as $45^{\circ} \mathrm{C}$ in the day and as low as $15^{\circ} \mathrm{C}$ when night falls. The highest record temperature was $47^{\circ} \mathrm{C}$, while the lowest record temperature was $5^{\circ} \mathrm{C}$. This high temperature contributed to why Maiduguri is considered as a place of high potential in solar energy exploration for rural electrification.

\subsubsection{Jos}

Jos is located in the Middle Belt of Nigeria with a population of about 900,000 residents based on the 2006 census. Popularly called "J-town", it is the administrative capital of Plateau State. It is located at latitude of $9^{\circ} 56^{\prime} \mathrm{N}$ of the equator and at a longitude of 


\begin{tabular}{|c|c|c|c|c|c|c|}
\hline Impact Factor: & $\begin{array}{l}\text { ISRA (India) } \\
\text { ISI (Dubai, UAF } \\
\text { GIF (Australia) } \\
\text { JIF }\end{array}$ & $\begin{array}{l}=1.344 \\
=0.829 \\
=0.564 \\
=1.500\end{array}$ & $\begin{array}{l}\text { SIS (USA) } \\
\text { PИНЦ (Russia) } \\
\text { ESJI (KZ) } \\
\text { SJIF (Morocco) }\end{array}$ & $\begin{array}{l}=0.912 \\
=0.234 \\
=\mathbf{3 . 8 6 0} \\
=\mathbf{2 . 0 3 1}\end{array}$ & $\begin{array}{l}\text { ICV (Poland) } \\
\text { PIF (India) } \\
\text { IBI (India) }\end{array}$ & $\begin{array}{l}=6.630 \\
=1.940 \\
=4.260\end{array}$ \\
\hline
\end{tabular}

$8^{\circ} 53^{\prime} \mathrm{E}$. it has a very high elevation, probably the highest in the country. Jos enjoys a more temperate climate than many of the rest of Nigeria. Average monthly temperatures range from $21-25^{\circ} \mathrm{C}(70$ $77^{\circ} \mathrm{F}$ ), and from mid-November to late January, night-time temperatures drop as low as $11^{\circ} \mathrm{C}$.

\subsubsection{Ogbomoso}

Ogbomosho is a city in Oyo State, southwestern Nigeria. It is located at latitude $8^{\circ} 08^{\prime} \mathrm{N}$ of equator and a longitude of $4^{\circ} 15^{\prime} \mathrm{E}$. The city has a tropical climate. The average annual temperature in Ogbomosho is $26.1{ }^{\circ} \mathrm{C}$. The temperatures are highest on average in March, at around $28.5^{\circ} \mathrm{C}$. August tends to have the lowest temperature of $24.0^{\circ} \mathrm{C}$ on an average.

\subsubsection{Enugu}

Enugu is the capital of Enugu State in Nigeria. It is located in south eastern Nigeria with a population of 722,664 according to the disputed 2006 Nigerian census and nearly 2 million according to 2015 estimates. It is located at $6^{\circ} 27^{\prime} 9.60^{\prime \prime} \mathrm{N}$ latitude of the equator and longitude of $7^{\circ} 30^{\prime} 37.20^{\prime \prime} \mathrm{E}$. The name Enugu implies hill-top though the city lies at the foot of an escarpment and not a hill. Enugu is located in a tropical rain forest zone with a derived savannah.

\subsubsection{Port-Harcourt}

Port-Harcourt is the capital and largest city of Rivers State and lies along the Bonny River and located in the Niger Delta. According to the 2006 census, the Port Harcourt urban area has a population of $1,382,592$. It is located at latitude $4^{\circ} 49^{\prime} 27^{\prime \prime} \mathrm{N}$ of the equator and longitude $7^{\circ} 2^{\prime} 1^{\prime \prime} E$. Port Harcourt features a tropical wet climate with lengthy and heavy rainy seasons and very short dry seasons. Only the months of December and January truly qualify as dry season months in the city. Temperatures throughout the year in the city are relatively constant, showing little variation throughout the course of the year. Average temperatures are typically between $25{ }^{\circ} \mathrm{C}-28{ }^{\circ} \mathrm{C}$.

\section{Materials and Method}

\section{Development of Mathematical Models}

Solar time ( $\left.t_{s}\right)$ : which is based on apparent angular motion of the sun across the sky is given by:

At solar noon, $\mathrm{t}_{1}=12 \mathrm{~h}$, it is given by: where

$$
t_{S}=t_{C}+E+\frac{\theta}{15^{0}}-Z_{e}
$$

$t_{C}$ is civil time in hours corresponding to the midpoint of each time step.

$\theta$ is the longitude in degrees of the site location. GMT.

$Z_{e}$ is the time zone in hours to the east of

$E$ is the equation of time in hours. Thus,

$$
\begin{aligned}
& E=3.82(0.000075+0.001868 \cos B- \\
& 0.032077 \sin B-0.014615 \cos 2 B- \\
& 0.04089 \sin 2 B) \\
& B=(d-1) \frac{360^{\circ}}{365}
\end{aligned}
$$

where

$$
\mathrm{d}=\text { day of the year, starting with } 1 \text { for January }
$$
$1^{\text {st }}$, that is $1 \leq d \leq 365$

At the summer solstice on June $21^{\text {st }}$, it is $23.45^{0}$ at the winter solstice on December $21^{\text {st }}$ in the northern hemisphere. i.e. $-23-45^{0} \leq \delta \leq 23.45^{0}$

At the intervening periods of the year, the solar declination angle can be approximated by a sinusoidal variation as:

$$
\delta=23.45^{0} \sin \left(360^{0} \frac{284+d}{365}\right)
$$

where

$(\delta)$ Declination angle is the angle made by the line joining the centre of the sun and the earth with its projection on the equatorial plane. At the annual and vertical equinoxes, it is zero.

Hour angle $(\omega)$ : this is the angular displacement of the sun, East or West of the total meridian due to the rotation of the earth on its axis at $15^{0}$ per hour, which expresses the time of the day with respect to solar noon is:

$$
\omega=\left(t_{s}-12\right) 15^{0}
$$

While the sunset hour angle is defined as:

$$
\omega_{S}=\cos ^{-1}[-\tan \delta \tan \varphi]
$$

where

$\omega$ is hour angle in degrees

$\omega_{S}$ is sunset hour angle in degrees.

At any point in time (between sunrise and sunset), the extra-terrestrial horizontal radiation is:

$$
\begin{aligned}
& I_{0}=I_{S C}\left(1+0.033 \cos \frac{360 d}{365}\right)[\sin \delta \sin \varphi+ \\
& \cos \delta \cos \varphi]
\end{aligned}
$$

Extraterrestrial radiation on a horizontal surface is the theoretical possible radiation that would be available if there were no atmosphere. The total daily extraterrestrial radiation on a horizontal surface is obtained by integrating equation (7) over the period from sunrise to sunset. i.e.

$$
\begin{aligned}
& H_{0}=\frac{24}{\pi} I_{S C}\left(1+0.033 \cos \frac{360 d}{365}\right) \times \\
& {\left[\frac{\pi \omega_{S}}{180} \sin \delta \sin \varphi+\cos \delta \cos \varphi\right]}
\end{aligned}
$$

The monthly mean daily extraterrestrial radiation on a horizontal surface is:

$$
\overline{H_{0}}=\frac{1}{D} \sum_{d_{m}=1}^{D} H_{0}\left(d_{m}\right)
$$




\begin{tabular}{|c|c|c|c|c|c|c|}
\hline Impact Factor: & $\begin{array}{l}\text { ISRA (India) } \\
\text { ISI (Dubai, UAF } \\
\text { GIF (Australia) } \\
\text { JIF }\end{array}$ & $\begin{array}{l}=1.344 \\
=0.829 \\
=0.564 \\
=1.500\end{array}$ & $\begin{array}{l}\text { SIS (USA) } \\
\text { PИНЦ (Russia) } \\
\text { ESJI (KZ) } \\
\text { SJIF (Morocco) }\end{array}$ & $\begin{array}{l}=0.912 \\
=0.234 \\
=\mathbf{3 . 8 6 0} \\
=\mathbf{2 . 0 3 1}\end{array}$ & $\begin{array}{l}\text { ICV (Poland) } \\
\text { PIF (India) } \\
\text { IBI (India) }\end{array}$ & $\begin{array}{l}=6.630 \\
=1.940 \\
=4.260\end{array}$ \\
\hline
\end{tabular}

Where $d_{m}$ is the day of the month and D is the total number of days in the month.

The ratio of the monthly mean daily global radiation on horizontal surface to monthly mean daily extraterrestrial horizontal radiation is called "Clearance index" given by:

$$
K_{T}=\frac{\bar{H}}{H_{0}}
$$

Mean Bias Error (MBE) is defined as:

$$
M B E=\frac{1}{P} \sum_{p=1}^{P}\left(\bar{H}_{e s t}-\bar{H}_{o b s}\right)
$$

Root Mean Square Error (RMSE) is defined as:

$$
R M S E=\sqrt{\frac{1}{P}\left[\sum_{P=1}^{P}\left(\bar{H}_{e s t}-\bar{H}_{o b s}\right)^{2}\right]}
$$

$\mathrm{t}$ - Statistic (TS) is defined as:

$$
T S=\sqrt{\left[\frac{(P-1)(M B E)^{2}}{\left(R M S E^{2}-M B E^{2}\right)}\right]}
$$

where $\bar{H}_{o b s} \quad$ is the observed $\bar{H}\left(k W h / m^{2} /\right.$ day $), \bar{H}_{e s t} \quad$ is the estimated $\bar{H}\left(k W h / m^{2} /\right.$ day $)$, and $\mathrm{P}$ is the number of observations and it corresponds to the twelve months $(\mathrm{P}=12)$ of the year.

Given the data points of the form $\left(\mathrm{x}_{\mathrm{p}} \mathrm{y}_{\mathrm{p}}\right)$ for $\mathrm{P}=$ $1,2, \mathrm{~K}$ set of point and that $\mathrm{y}_{\mathrm{p}}$ depends linearly on $\mathrm{x}_{\mathrm{p}}$, then, for accurate prediction of the set points, it is necessary to obtain the slope $\mathrm{m}$ and $\mathrm{H}$ - intercept $\left(\mathrm{m}_{\mathrm{o}}\right)$ of a time that best fits those dataset points, defined by:

$$
y_{P}=m_{o}+m x_{P}
$$

If $\mathrm{x}_{\mathrm{p}}$ are $\mathrm{j}$ independent variables $\left(\mathrm{x}_{1 \mathrm{p}}, \mathrm{x}_{2 \mathrm{p}}, \ldots, \mathrm{x}_{\mathrm{jp}}\right)$, then equation (14) becomes

$$
y_{P}=m_{o}+m_{1} x_{1 P}+m_{2} x_{2 P} \pm \cdots \ldots+m_{j} x_{j P}
$$

The coefficients of determination defined by

$R^{2}=\sum_{P=1}^{P}\left(m_{o}+m_{1} x_{1 P}+\cdots \ldots+m_{j} x_{j P}-y_{P}\right)$

Where $x$ is the independent variable, $\mathrm{j}$ is the number of independent variable which would minimize the sum of squares of the difference between the data and the estimated time and $\mathrm{R}$ is the coefficient of correlation.
Two independent valuables $\mathrm{j}$ in equation (16) equals to 2 are assumed. If the dependent variable of equation (16) is the clearance index $\mathrm{K}$ and the independent variable are the monthly average daily air temperature ratio, $\overline{T_{R}}$ and the monthly average daily maximum air temperature $\overline{T_{\max }}$, then equation (16) becomes

$$
K_{P}=m_{o}+m_{1} \bar{T}_{R P}+m_{2} \bar{T}_{\max P}
$$

Where the subscripts $\mathrm{P}(=1,2,---12)$ refers to the monthly average daily dataset for a typical year.

In matrix form, equation (17) becomes

$$
\left[\begin{array}{c}
K_{1} \\
\vdots \\
K_{P}
\end{array}\right]=\left[\begin{array}{ccc}
1 & \bar{T}_{x 1} & \bar{T}_{\max P} \\
\vdots & & \\
1 & \bar{T}_{R P} & \bar{T}_{\max P}
\end{array}\right]\left[\begin{array}{c}
m_{o} \\
\vdots \\
m_{1}
\end{array}\right]
$$

$$
\text { i.e. } K=A M
$$

where $K=P \times 1$ column matrix, A is $P \times 3$ matrix and $\mathrm{M}$ is $(j \times 1) \times 1$ matrix. To solve for $\mathrm{A}$, there is the need to transform A to a square matrix (where $P \neq j \neq 1$ ).

$$
A^{T} K=A^{T} A M
$$

where $A^{T}$ is the transpose of $\mathrm{A}$.

$$
\text { If }\left(A^{T} A\right)^{-1} \text { exits, then }
$$

$$
M=\left(A^{T} A\right)^{-1} A^{T} K
$$

The solution of equation (21) is a matrix of empirical constants, $M=\left[m_{0}, m_{1}, m_{2}\right]$.

\section{Performance Evaluation}

The performance evaluation of the generalized model was done by computing the t-statistic (t-value) in terms of the mean-bias error (MBE), and the root mean square error (RMSE) and the analysis done at 95\% confidence level. The t- statistic (t- value) is computed in terms of the mean bias error (MBE) and the root mean square error (RMSE) and analyzed at the $95 \%$ confidence level.

The t- statistic is a known statistical tool with an exceptionally satisfactory accuracy for analyzing solar radiation data. The coefficients of determination $\left(\mathrm{R}^{2}\right)$ of the estimation model are obtained.

The temperature - based linear regression models for the seven locations used as case studies in this paper are:

$$
\begin{array}{ll}
\bar{H}_{\text {Sok }}=\bar{H}_{0}\left(-1.3142+0.3512 \bar{R}_{T}+0.0632 \bar{T}_{\text {max }}\right) & \text { for Sokoto } \\
\bar{H}_{\text {Kad }}=\bar{H}_{0}\left(0.2826-1.0754 \bar{R}_{T}+0.0521 \bar{T}_{\text {max }}\right) & \text { for Kaduna } \\
\bar{H}_{\text {Maid }}=\bar{H}_{0}\left(0.6021-0.3214 \bar{R}_{T}+0.0085 \bar{T}_{\text {max }}\right) & \text { for Maiduguri } \\
\bar{H}_{\text {Jos }}=\bar{H}_{0}\left(2.5021-2.9218 \bar{R}_{T}+0.0184 \bar{T}_{\text {max }}\right) & \text { for Jos } \\
\bar{H}_{\text {Ogb }}=\bar{H}_{0}\left(0.2614-0.8921 \bar{R}_{T}+0.0248 \bar{T}_{\text {max }}\right) & \text { for Ogbomoso }
\end{array}
$$




$$
\begin{array}{ll}
\bar{H}_{\text {Enugu }}=\bar{H}_{0}\left(0.7176-0.5864+0.0214 \bar{T}_{\text {max }}\right) & \text { for Enugu } \\
\bar{H}_{\text {Port }}=\bar{H}_{0}\left(0.8214-0.6321 \bar{R}_{T}+0.5889 \bar{T}_{\text {max }}\right) & \text { for Port - Harcourt }
\end{array}
$$

Combining (22) and (28) the generalized twoparameter temperature based linear model is

$$
\bar{H}=\overline{H_{0}}\left(0.9347-0.2894 R_{T}+0.3827 T_{\max }\right)
$$

From equation (22) to (29), it is observed that a significant statistical relationship (with coefficient of correlation COC) of 86.3 to $94.6 \%$ ) exists between the clearance index, ambient temperature ratio and maximum ambient temperature with linear regression model. Equation 29 can be written as:

$$
\bar{H}=\bar{H}_{0}\left(m_{0}+m_{1} \bar{R}_{T}+m_{2} \bar{R}_{T \text { max }}\right)
$$

The ambient temperature ratio is

$$
\bar{R}_{T}=\frac{\overline{\bar{T}}_{\text {min }}}{\overline{\bar{T}}_{\text {max }}}
$$

where

$\bar{H}, \bar{H}_{0}, \bar{R}_{T}, \bar{T}_{\text {min }}$ and $\bar{T}_{\text {max }}$ are the respective monthly mean daily horizontal global and extraterrestrial - radiation, minimum to maximum ambient temperature, $m_{0}, m_{1}$ and $m_{2}$ are empirical constants.

The model is very useful in estimating the global solar radiation on horizontal surfaces at different locations on the geopolitical zones in Nigeria.

\section{Discussion of results.}

Figures 1 to 4 show the empirical constants for the seven selected locations used as case studies in this research paper. Observation shows that Jos has the highest empirical constant of 0.6814 while Sokoto has least empirical constant of - 0.2650 because. Sokoto in the North -Western Nigerian has a relatively high annual solar irradiance and far much more than the $1.361 \mathrm{~kW} / \mathrm{m}^{2} / \mathrm{d}$ benchmark. Same goes for the rest, as Kaduna, Maiduguri, Ogbomosho, Jos, Enugu and Port-Harcourt.

A significant statistical relationship with coefficient of correlation (COC) of $94.6 \%$ between the clearance index ,ambient temperature ratio and maximum ambient temperature with linear regression model .The COC for Sokoto, Kaduna, Maiduguri and Jos are $92.75 \%, 94.6 \%, 86.3 \%$ and $91.6 \%$ respectively while the COC for Ogbomoso, Enugu, Port-Harcourt are $91.9 \%, 90.5 \%$ and $93.7 \%$ respectively as shown in Figure 5-7.

Sokoto has a coefficient of determination COD of $88.6 \%$, Kaduna, Maiduguri and Jos have a COD of $92.2 \%, 77.9 \%$ and $86.5 \%$ respectively while Ogbomoso, Enugu and Port-Harcourt have a COD of $87.1 \%, 84.5 \%$ and $82.4 \%$ respectively. This is because it is important to note that Maiduguri has the highest annual irradiance in the whole of the sites under consideration, and has the highest potential for the generation of solar energy.
Kaduna has the highest $\mathrm{COC}$ of $94.6 \%$ and a highest COD of $92.2 \%$ as a result of the level of industrial activities in the city. Most of the industries in this city are operating at maximum efficiency. Maiduguri has the least COC and COD of $86.3 \%$ and $77.9 \%$ respectively because most of industries in this city are not operating at their maximum efficiencies, hence the city is not as industrialized as Kaduna compared to all the cities used as case studies in this research paper.

In order to achieve a more reliable statistical result, an additional tool TS is used since it is possible to have a large value of RMSE as well as small values of MBE. The smaller the value of TS, the better the performance of the models. The TS value of the models developed are within the range of critical value of 1.96 as shown in Figure 8-10. A low TS value of the models developed (0.0498 0.7884 ) shows an excellent performance of the models.

The RMSE values which are a measure of the accuracy of estimation vary from 0.1835 (the least) to 0.2887 (highest) for Kaduna and Maiduguri respectively. This shows that Kaduna city is more industrialized than Maiduguri. Sokoto, Jos, Ogbomoso, Enugu and Port-Harcourt have RMSE values of $0.2848,0.2416,0.2213,0.1520$ and 0.2104 respectively. Port-Harcourt recorded the highest MBE value of 0.0724 while Jos recorded the least MBE value of -0.0426 as illustrated in figure 8 . Figure 10 illustrates the relationship between the TS of the selected cities used as case studies. PortHarcourt recorded the highest TS value of 0.7884 while Maiduguri recorded the least TS value of 0.0498 due to Even though, the solar radiation is generally high throughout the year in Maiduguri, Feb-April represent the months with the highest solar radiation and August is the month with the lowest solar radiation. On the overall this location is the very top site for solar power exploration in Nigeria. The TS values of Sokoto, Kaduna, Jos, Ogbomoso and Enugu are 0.1572, 0.0682, 0.5730, 0.0940 and 0.0983 respectively.

Figure11 shows the relationship between the MBE, RMSE and the TS for the selected locations. The RMSE values vary from - 0.0426 (the least for Jos) to 0.0724 (the highest for Port-Harcourt). The MBE values obtained are positive for Kaduna, Enugu and Port-Harcourt while the MBE values are negative for Sokoto, Maiduguri, Jos and Ogbomoso. This shows that the models vary between over and under estimation of $\mathrm{H}$. The value of MBE from the model for Ogbomoso has the highest underestimation compared to Port-Harcourt.

Jos has one of the best solar irradiance in the country and it represents a place of huge potential in 


\begin{tabular}{|c|c|c|c|c|c|c|}
\hline Impact Factor: & $\begin{array}{l}\text { ISRA (India) } \\
\text { ISI (Dubai, UAF } \\
\text { GIF (Australia) } \\
\text { JIF }\end{array}$ & $\begin{array}{l}=1.344 \\
=0.829 \\
=0.564 \\
=1.500\end{array}$ & $\begin{array}{l}\text { SIS (USA) } \\
\text { PИНЦ (Russia) } \\
\text { ESJI (KZ) } \\
\text { SJIF (Morocco) }\end{array}$ & $\begin{array}{l}=0.912 \\
=0.234 \\
=3.860 \\
=\mathbf{2 . 0 3 1}\end{array}$ & $\begin{array}{l}\text { ICV (Poland) } \\
\text { PIF (India) } \\
\text { IBI (India) }\end{array}$ & $\begin{array}{l}=6.630 \\
=1.940 \\
=4.260\end{array}$ \\
\hline
\end{tabular}

the solar exploration market. Jos has a very high elevation and altitude and can have a potential for exploring a verse array of other renewable energy technologies like wind energy, geothermal etc. Ogbomoso is very similar to Jos in terms of the solar irradiance; it is generally a good place for solar energy exploration.

Enugu and Port-Harcourt hove low solar irradiance compared to other locations considered in this research, but is still far higher than the $1.361 \mathrm{~kW} / \mathrm{m}^{2} / \mathrm{d}$ standard, but due to load level in this area which might be high due to high commercial activities, hybrid form of off-grid rural electrification will be more efficient in satisfying the energy demand of this site. February to April stood out as the month with the highest solar irradiance, and therefore the months with highest potential. June to August are characterised with a general drop in energy generated by the sun's radiation.

The cities experienced a decrease in the horizontal global solar radiation from July to October (during raining season) with Ogbomoso having the lowest monthly mean daily horizontal global solar radiation of $4.24 \mathrm{kWh} / \mathrm{m}^{2} /$ day in June. During dry season period, when others experienced a rapid increase in their solar radiation, only Maiduguri maintained a gradual decrease in the global radiation with a least radiation of $6.23 \mathrm{kWh} / \mathrm{m}^{2} /$ day in November. The variation of daily horizontal global solar radiation with months of the year in Maiduguri differs from other cities due to their geographical locations.

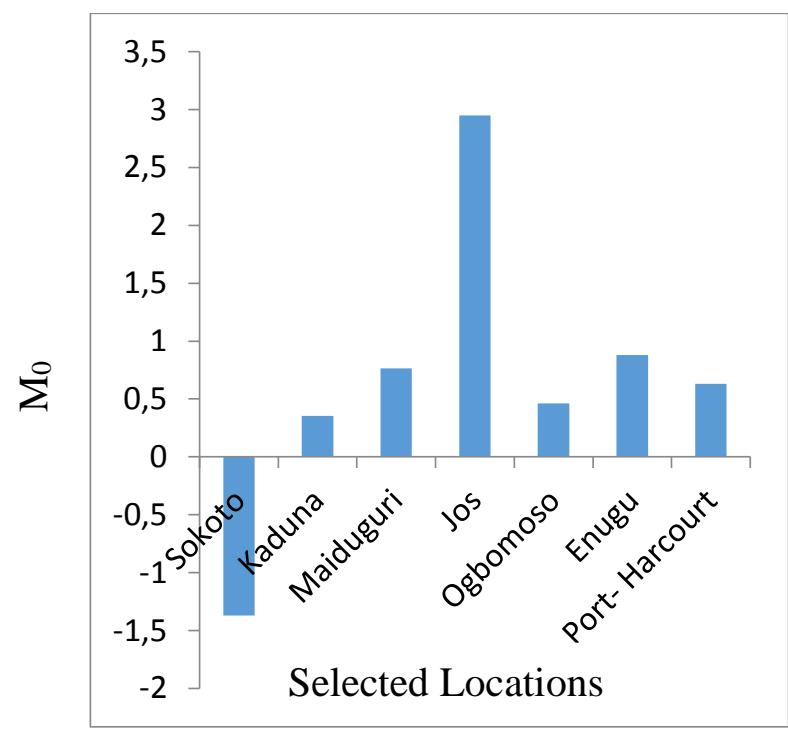

Figure 1 - Empirical Constants (mo) of the Selected Locations.

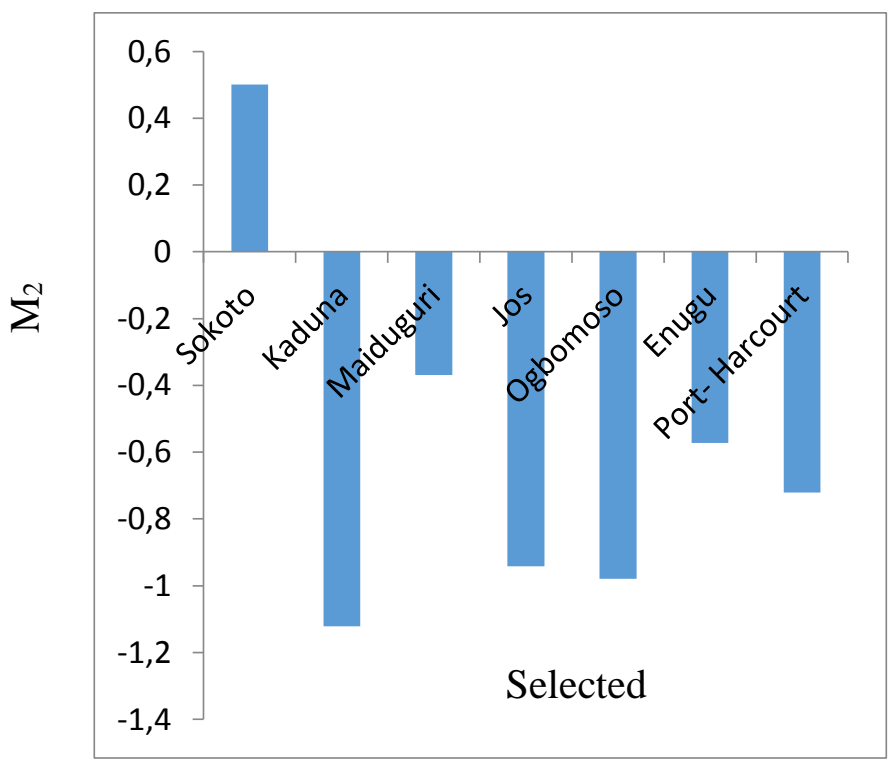

Figure 2 - Empirical Constants $\left(\mathrm{m}_{2}\right)$ of Selected Locations. 


\begin{tabular}{|c|c|c|c|c|c|c|}
\hline Impact Factor: & $\begin{array}{l}\text { ISRA (India) } \\
\text { ISI (Dubai, UAE } \\
\text { GIF (Australia) } \\
\text { JIF }\end{array}$ & $\begin{array}{l}=1.344 \\
=0.829 \\
=0.564 \\
=1.500\end{array}$ & $\begin{array}{l}\text { SIS (USA) } \\
\text { PИНЦ (Russia) } \\
\text { ESJI (KZ) } \\
\text { SJIF (Morocco) }\end{array}$ & $\begin{aligned} &= \mathbf{0 . 9 1 2} \\
&=\mathbf{0 . 2 3 4} \\
&=\mathbf{3 . 8 6 0} \\
&=\mathbf{2 . 0 3 1}\end{aligned}$ & $\begin{array}{l}\text { ICV (Poland) } \\
\text { PIF (India) } \\
\text { IBI (India) }\end{array}$ & $\begin{array}{l}=6.630 \\
=1.940 \\
=4.260\end{array}$ \\
\hline
\end{tabular}

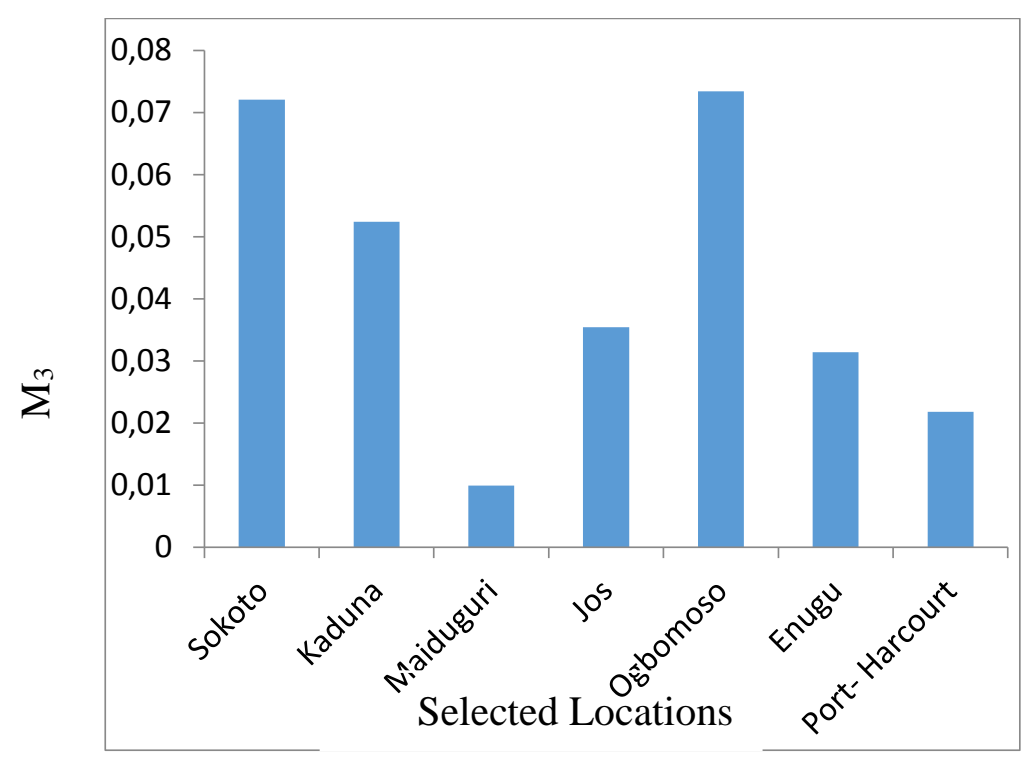

Figure 3 - Empirical Constants $\left(\mathrm{m}_{3}\right)$ of the Selected Locations.

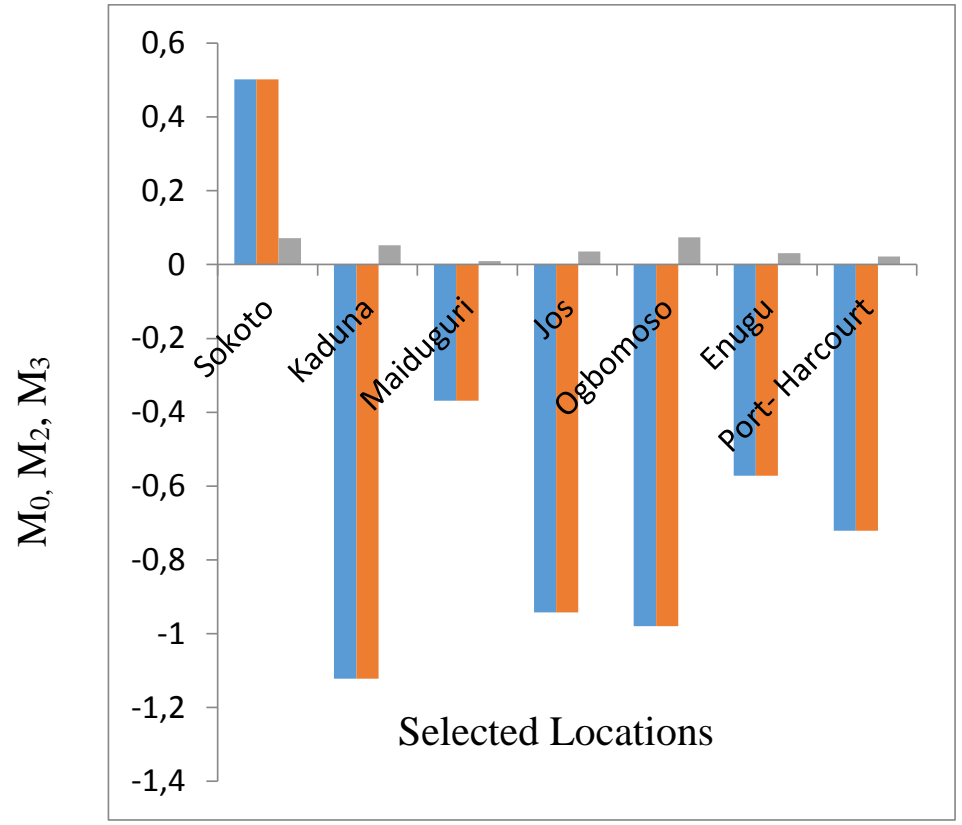

Figure 4 - Combined Empirical Constants of the Selected Locations. 


\begin{tabular}{|c|c|c|c|c|c|c|}
\hline Impact Factor: & $\begin{array}{l}\text { ISRA (India) } \\
\text { ISI (Dubai, UAE } \\
\text { GIF (Australia) } \\
\text { JIF }\end{array}$ & $\begin{array}{r}=1.344 \\
=0.829 \\
=0.564 \\
=1.500\end{array}$ & $\begin{array}{l}\text { SIS (USA) } \\
\text { PИНЦ (Russia) } \\
\text { ESJI (KZ) } \\
\text { SJIF (Morocco) }\end{array}$ & $\begin{array}{l}=0.912 \\
=0.234 \\
=\mathbf{3 . 8 6 0} \\
=\mathbf{2 . 0 3 1}\end{array}$ & $\begin{array}{l}\text { ICV (Poland) } \\
\text { PIF (India) } \\
\text { IBI (India) }\end{array}$ & $\begin{array}{l}=6.630 \\
=1.940 \\
=4.260\end{array}$ \\
\hline
\end{tabular}

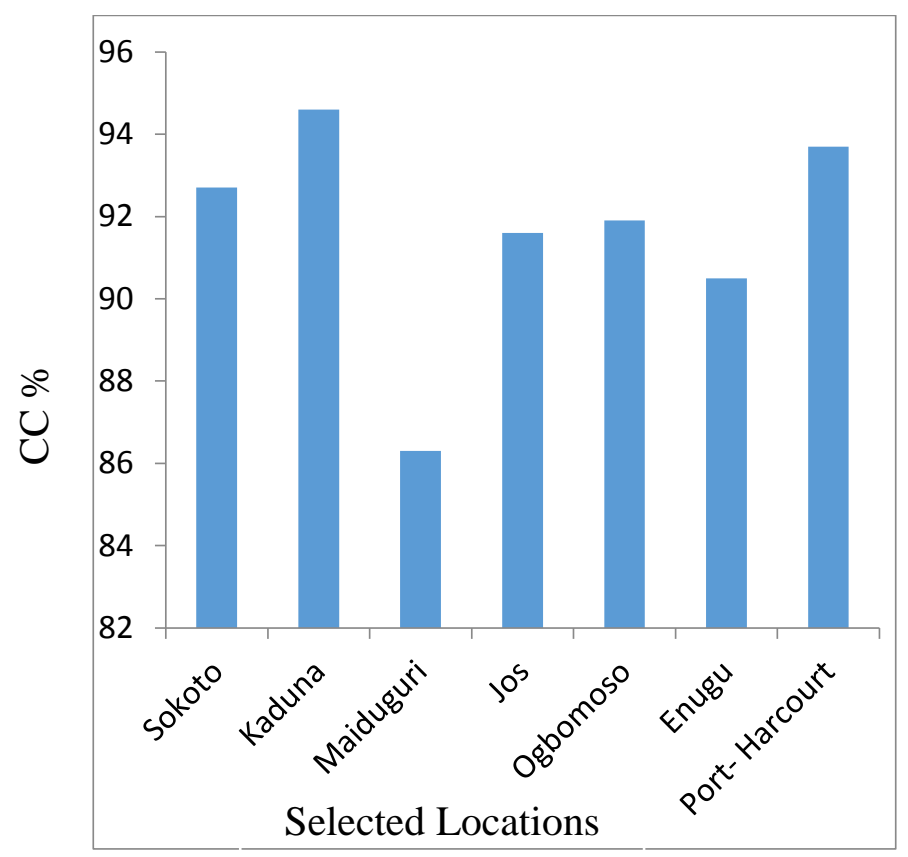

Figure 5 - Coefficients of Correlation of the Selected Locations.

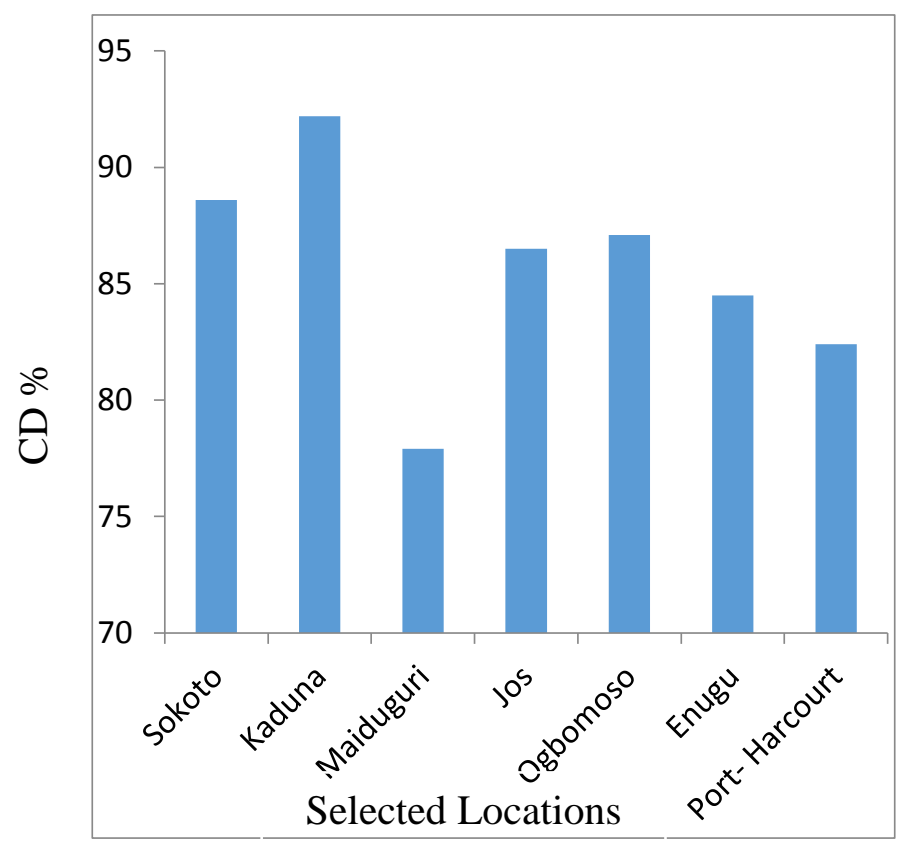

Figure 6 - Coefficients of Determination of the Selected Location. 


\begin{tabular}{|c|c|c|c|c|c|c|}
\hline Impact Factor: & $\begin{array}{l}\text { ISRA (India) } \\
\text { ISI (Dubai, UAE } \\
\text { GIF (Australia) } \\
\text { JIF }\end{array}$ & $\begin{array}{l}=1.344 \\
=0.829 \\
=0.564 \\
=1.500\end{array}$ & $\begin{array}{l}\text { SIS (USA) } \\
\text { PИНЦ (Russia) } \\
\text { ESJI (KZ) } \\
\text { SJIF (Morocco) }\end{array}$ & $\begin{array}{l}=0.912 \\
=0.234 \\
=3.860 \\
=2.031\end{array}$ & $\begin{array}{l}\text { ICV (Poland) } \\
\text { PIF (India) } \\
\text { IBI (India) }\end{array}$ & $\begin{array}{l}=6.630 \\
=1.940 \\
=4.260\end{array}$ \\
\hline
\end{tabular}

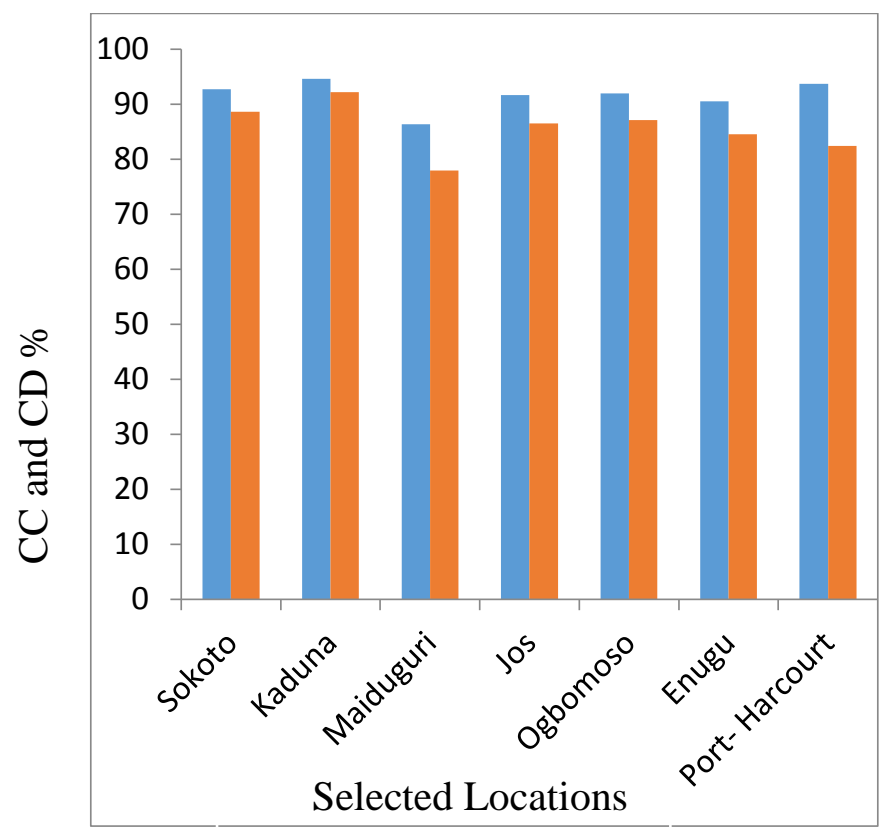

Figure 7 - Coefficients of Correlation and Coefficient of Determination of the Selected Location.

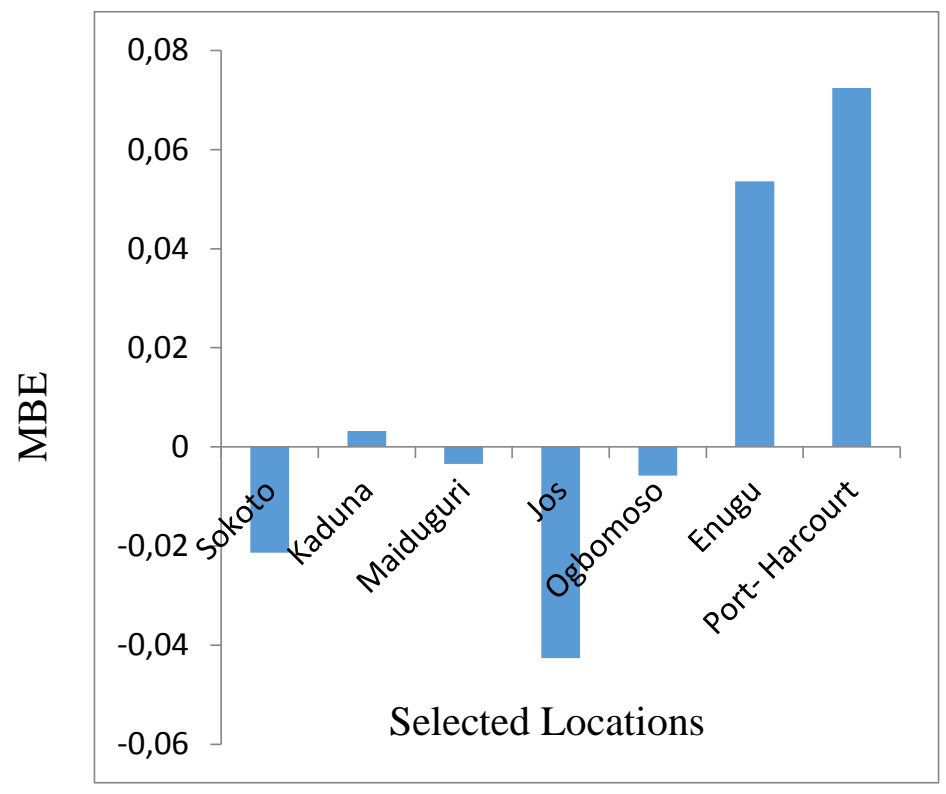

Figure 8 - MBE of the Selected Locations. 


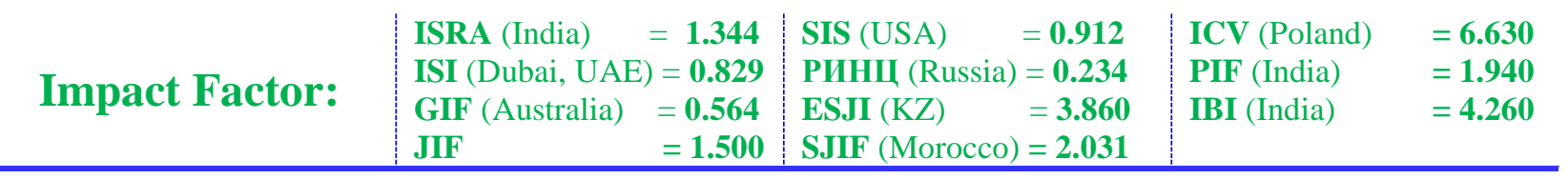

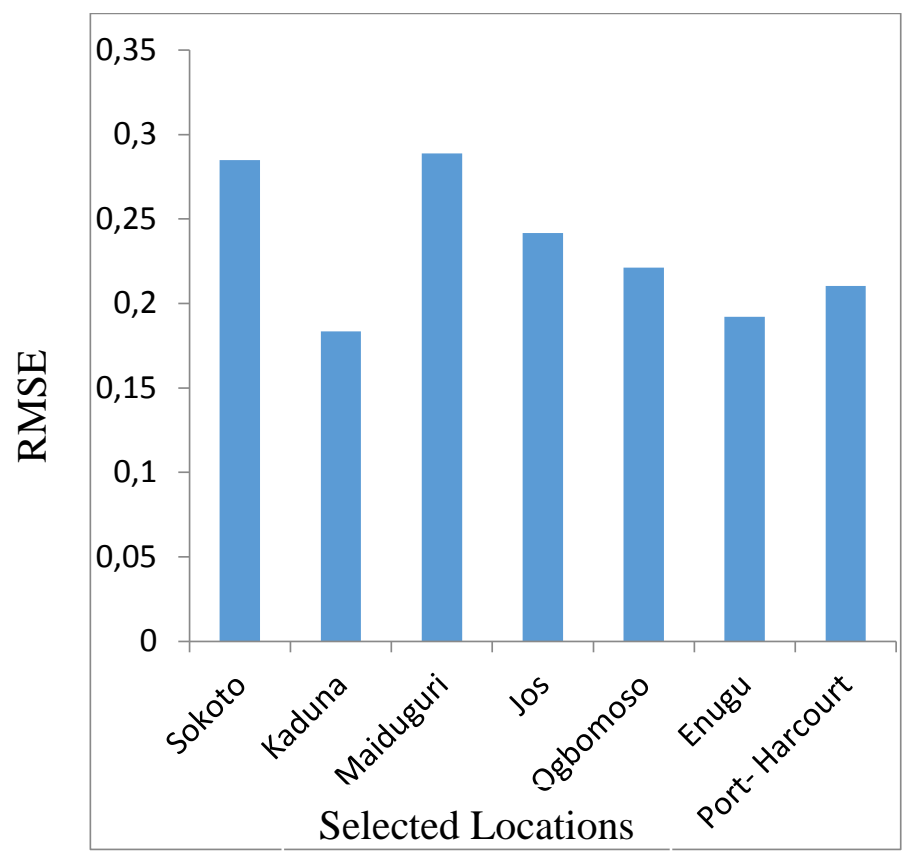

Figure 9 - RMSE of the Selected Locations.

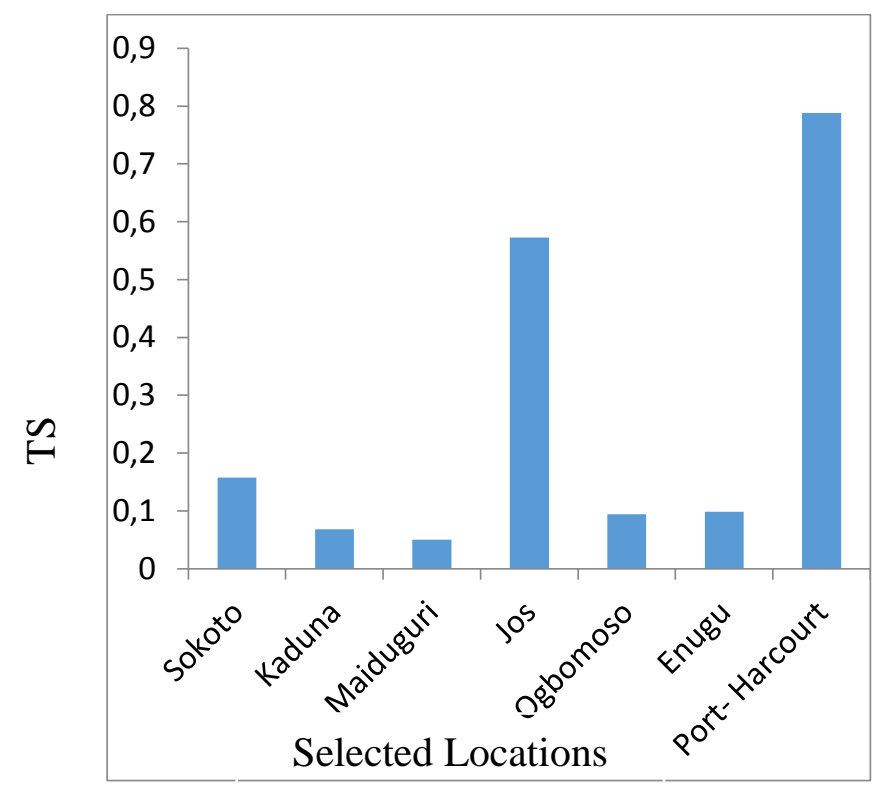

Figure 10 - TS of the Selected Locations. 


\begin{tabular}{l|lrl|l|ll} 
& ISRA (India) & $=\mathbf{1 . 3 4 4}$ & SIS (USA) & $=\mathbf{0 . 9 1 2}$ & ICV (Poland) & $=\mathbf{6 . 6 3 0}$ \\
Impact Factor: & ISI (Dubai, UAE) $=\mathbf{0 . 8 2 9}$ & PVHIL (Russia) $=\mathbf{0 . 2 3 4}$ & PIF (India) & $=\mathbf{1 . 9 4 0}$ \\
& GIF (Australia) & $\mathbf{0 . 5 6 4}$ & ESJI (KZ) & $=3.860$ & IBI (India) & $=\mathbf{4 . 2 6 0}$
\end{tabular}

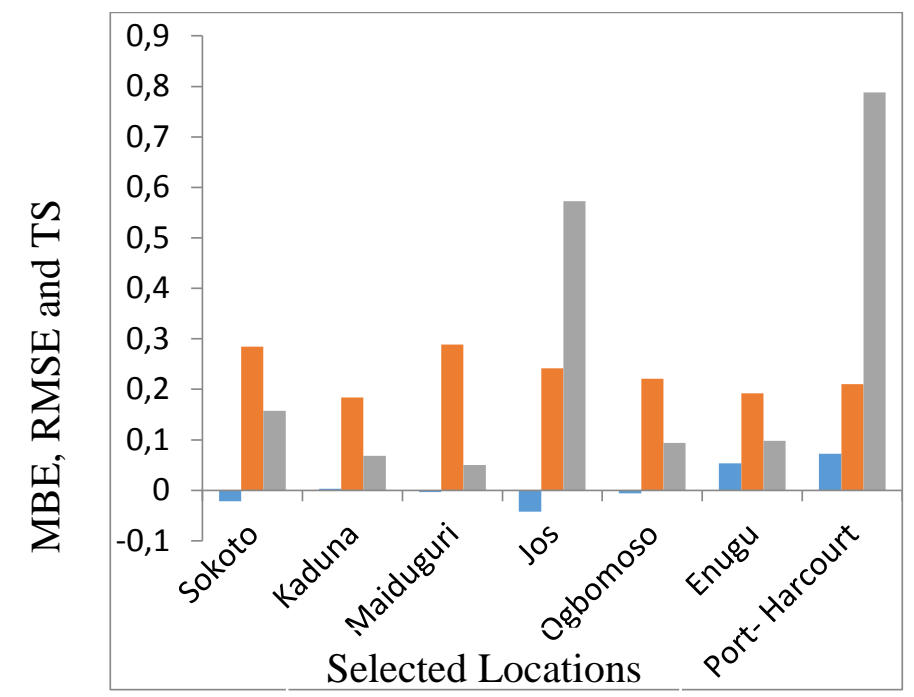

Figure 11 - MBE, RMSE and TS of the Selected Locations.

\section{Conclusion}

A Generalized two - parameter temperature based linear model for assessment of solar irradiance on Nigerian geo-political zones has been developed. The minimum and maximum monthly mean daily ambient temperatures as well as the monthly mean daily global solar radiation from NASA were collected and analyzed over a twenty years period for seven selected locations that cut across Nigerian geopolitical zones. Appropriate mathematical notations were used to perform a stochastic analysis on the collected data to develop the modified model.

The results of the generalized model developed which indicates low value of MBE (0.0327) generalized suggested that it has a good long - term representation of the physical problems.
The RMSE is in the range of 0.1835 to 0.2887 indicating the efficiency of the generalized model. The global solar radiation intensity produced by the generalized model can be used in the design, analysis and performance estimation of the solar energy conversion system. This model can be applied to other locations not considered in this research paper. This model can replace the existing sunshine - based model. The estimation of the average daily global solar radiation which is necessary for optimal economic sizing of solar photovoltaic systems will encourage extensive use of solar energy, which is considered as essential solution to high atmospheric pollution caused from fossil fuel combustion.

\section{References:}

1. Akpabio LE, Udo SO, Etuk SE (2004) "Emperical correlations of global solar radiation with metrological data for Nigeria", Turkish Journal of Physics, Volume 28, Number 3, p. 301-307.

2. Alam MS, Saha SK, Chowdhury MAK, Safuzzaman M, Rahman M (2005) "Simulation of solar radiation system", Journal of Applied Sciences, Volume 2, Number 4, p. 751-758.

3. Almorox J, Benito M, Hontoria C (2005) "Estimation of monthly angstrom-prescott equation coefficients from measured daily data in Toledo, Spain", Renewable Energy, Volume 30, Number 6, p. 931-936.
4. Alsalihi AM, Kadum MM, Mohammed AJ (2010) "Estimation of global solar radiation on horizontal surface using meterological measurement for different cities in Iraq", Asian Journal of Scientific Research, Volume 3, Number 4, p. 240-248.

5. Angstrom AS (1924) "Solar and terrestrial radiation", Metrological Society, Volume 50, p. 121-126.

6. Angustine C, Nnabuchi MN (2009) "Correlation between sunshine hours and global solar radiation in Warri, Nigeria", Pacific Journal of Science and Technology, Volume 10, Number 2, p. 574-579. 
7. Badescu V (1999) "Correlations to estimate monthly mean daily solar global irradiation: application to Romania", Energy, Volume 24, Number 10, p.883-893.

8. Burari FW, Sambo AS (2001) "Model for the prediction of global solar radiation for Bauchi using metrological data", Nigerian Journal of Renewable Energy, Volume 91, p. 30-33.

9. Che HZ, Shi GY, Zhang XY, Zhao JO, Li Y (2007) "Analysis of sky conditions using 40 year records of solar radiation data in China", Theoretical and Applied Climatology, Volume 89, Number 1-2, p. 83-94.

10. Copper PI (1969) "The absorption of radiation in solar cells" Solar Energy, Volume 12, Number 3, p. 333-346.

11. Cristobal JRS (2011) "A multicriteria data development analysis model to evaluate efficiency of the renewable energy technologies", Renewable Energy, Volume 36, Number 10, p. 2742-2746.

12. Duffie JA, Beckman WA (2006) "Solar engineering of thermal processes", John Wiley \& Son, New York, NY, USA, $3^{\text {rd }}$ Edition. p. 93125.

13. Falayi EO, Rabiu AB (2005) "Modeling global solar radiation using sunshine duration data", Nigeria Journal of Physics, Volume 17, p. 181186.

14. Falayi EO, Adeniran JO, Rabiu AB (2008) "Empirical models for the correlation of global solar radiation with metrological data for Iseyin, Nigeria", International Journal of Physical Sciences, Volume 3, Number 9, p. 210-216.

15. Halouani N, Nguyen CT, Ngoc DV (1993) "Calculation of monthly average global solar radiation on horizontal surfaces using daily hours of bright sunshine", Solar Energy, Volume 50, Number 3, p. 247-258.

16. Kamman C (2001) "Impact of rising atmospheric $\mathrm{CO}_{2}$ concentrations on the fluxes of the greenhouse gases $\mathrm{N}_{2} \mathrm{O}$ and $\mathrm{CH}_{4}$ in a grassland ecosystem", Thesis Giessen, Germany University of Giessen, p. 228-239

17. Kaplanis SN (2006) "New Methodologies to estimate the hourly global solar radiations comparisons with existing models", Renewable Energy, Volume 31, Number 6, p. 781-790.

18. Menges HO, Ertekin C, Sonmete MH (2006) "Evaluation of global solar radiation models for Konya, Turkey", Energy Conversation and management, Volume 47, Number 18, p. 31493173.

19. NASA (2010) "Surface metrological and solar energy data and information", Available: http://eosweb.iarc.nasa.gov/sse

(Accessed: 10.04.2017).
20. NIMA (2011) "Archives of Nigerian metereological agent (NIMA)", Oshodi, Lagos State, Nigeria. p. 131-152.

21. Obi C (2009) 'Nigeria's Niger Delta: understanding the complex drivers of violent oil-related conflict", Africa Development, Council for the Development of Social science Research in Africa, CODESRIA, Volume 34, Number 2, p. 103-128.

22. Okogbue EC, Adedokun JA (2002) "On the estimation of solar radiation at Ondo, Nigeria", Journal of Physics, Volume 4, p. 97-99.

23. Okudamiy MS, Nzeako AN (2010) "Empirical model for estimating global solar radiation on horizontal surfaces for selected cities in the six geo-political zones in Nigeria", Research Journal of Applied Science, Engineering and Technology, Volume 2, Number 8, p. 805-812.

24. Okudamiy MS, Nzaeko AN (2011) "Estimation of diffuse solar radiation for selected cities in Nigeria", ISRN Renewable Energy, Volume2, Number 11, p. 439-460.

25. Page JK (1994) "The estimation of monthly mean values of daily total short-wave radiation on vertical and inclined surfaces from sunshine records for latitude $40^{\circ} \mathrm{N}-40^{\circ} \mathrm{S}$ ", In Proceeding of the UN. Conference on New sources of Energy, p. 178-198.

26. Parry ML, Canzian OF, Palutikos JP, Vander Linden PJ, Hanson CE (2007) "Climate change: impacts, adaptation and vulnerability", Contribution of Working Group II to the Fourth Assessment Report of the IPCC, Cambridge, United Kingdom and Network, USA, Cambridge University Press. p. 976-989.

27. Safari B, Gasore J (2009) "Estimation of global solar radiation on horizontal surface in Rwanda using empirical model', Asian Journal of Science Research, Volume 2, p. 68-75.

28. Sfetsos A, Coonick AH (2000) "Univariate and multivariate forecasting of hourly solar radiation with artificial intelligent techniques", Solar Energy, Volume 68, p. 169-178.

29. Stone RJ (1993) "Improved statistical procedure for the evaluation of solar radiation estimation models", Solar Energy, Volume 51, Number 4, p. 289-291.

30. Trabea AA, Shaltout MAM (2000) "Correlation of global solar radiation with metrological parameters over Egypt", Renewable Energy, Volume 21, Number 2, p. 297-308.

31. Ulgen KS, Hepbasli A (2002) "Estimation of solar radiation parameters for IZMIR, Turkey", International Journal of Energy Research, Volume 26, Number 9, p. 807-823.

32. Ulgen KS, Hepbasli A (2002) "Prediction of solar radiation parameters through clearness index for IZMIR, Turkey", Energy Sources, Volume 24, Number 9, p. 773-785. 